\title{
Mexican Migration and the 160-Acre Water Limitation
}

\author{
Paul S. Taylor*
}

The author traces the parallel histories of the Mexican migration and U.S. land reclamation practice, focusing on the contrast between the asserted goals of public land reclamation policies and actual patterns of ownership. He urges Mexican Americans to take an active role in seeking enforcement or reform of the reclamation laws.

For more than 50 years, Mexican immigrants and braceros have been a primary labor source for irrigated farms of the western United States. Fleeing the turmoil of a Mexican agrarian revolution, inore Mexicans than at any prior or subsequent time came to this country between 1912 and 1930. They came to the land which Congress, through the National Reclamation Act of 1902, had intended to provide for the landless. Regrettably, this Act has gone largely unenforced and the national purpose einbodied therein unfulfilled. Ironically, migrants from 1 Mexico and their descendants now occupy a position in the United States much like that which spurred their flight fron Mexico, a position which the National Reclaination Act sought to prevent.

Historical accidents as well as weaknesses in legislation and its administration have thwarted the distribution of landownership among the inany. At the same time structural and technological changes in agriculture have been diminishing the numbers of working farmers and farm workers, and generating pressures which tend to reinforce the existence of large aggloinerations of land.

Yet in opposition to this general trend, a few Mexican-American farm workers have acquired farms which they operate with notable success. Whether such projects signal a new trend is a question for the future; the answer will depend on the winds of politics, law, economics, and the shaping of purpose among farm workers themselves.

* Professor of Economics Emeritus, University of California, Berkeley; consultant to the Office of the Secretary of the Interior and Bureau of Reclamation successively between 1943 and 1952. Martha Chase and Stefan Jovanovich assisted in preparation of this paper. The Institute of Business and Economic Research and the Committee on Research of the University of California, Berkeley, gave support. 
No right to the use of water for land in private ownership shall be sold for a tract exceeding one hundred and sixty acres to any one landowner, and no such sale shall be made to any landowner unless he be an actual bona fide resident on such land, or occupant thereof residing in the neighborhood of said land . . . .

\section{National Reclamation Act (1902)}

$$
* * *
$$

The Nation shall have at all times the right to impose on private property such limitations as the public interest may demand . . . . For this purpose necessary measures shall be taken . . . to divide large landed estates . . . to develop small landed holdings . . . to establish new centers of rural population with such lands and waters as may be indispensable to them . . . .

\section{Mexican Constitution (1917)}

Despite the serious obstacles that have impeded its practical effect, the declared policy in both the United States and Mexico for over two generations has been that land should be distributed among working farmers. Beginning with the Preemption Act of $1841,{ }^{3}$ the United States Congress passed three significant pieces of legislation attempting to effectuate this policy. The Preemption Act was enacted to halt the practice of acquiring paper title to lands already developed by settlers. These titled speculators had forced the settler either to share land whose value he had improved by his labors or to give it up. The Homestead Act, ${ }^{4}$ passed in 1862, opened 160 acres of public land to each actual settler on condition that he reside on the land and develop it. Finally, Congress passed the National Reclamation Act in 1902. It imposed a residency requirement and 160-acre limit on individual landholdings to receive water froin federal reclamation projects. ${ }^{5}$

Urging adoption of these limitations, the bill's sponsors had cited recent Latin American and Philippine revolts against land nonopolies. Failure to include acreage limitation in the reclamation bill to prevent monopoly "would have fastened upon this country all the evils of land monopoly which produced the great French revolution, which caused the revolt against church monopoly in South America and which in recent

1. 43 U.S.C. $\$ 431$ (1902).

2. Constitución FeDERAL art. 27 (Mexico, 1917), translated in E. Simpson, The ENIDO: MExICo's WAY OUT 66 (1937).

3. Act of Sept. 4, 1841, ch. 16, 5 Stat. 453.

4. Act of May 20, 1862, ch. 75, 12 Stat. 392.

5. 43 U.S.C. $\$ 431$ (1902). 
times has produced the outbreak of the Filipinos against Spanish authority," said Congressnuan Francis Newlands of Nevada. ${ }^{6}$

Congressional debate made reference to other dangers to stability. Congressman John Dalzell of Pennsylvania pointed out:

[A reclamation program] would draw off the surplus of unemployed labor in the East in any period of hard times, and . . . act as a safety valve and preserve stable conditions beneficial to both labor and capital. It would reheve us of the greatest danger to our social stability which confronts us today - the danger arising from the possible throwing out of employment of a multitude of men in some period of business depression, such as we passed through a few years ago. In such times as that strikes and riots are inevitable, and we have had experience enough in the past to show their danger. ${ }^{7}$

The desire was to preserve an open door of opportunity on the land. Thomas F. Walsh, President of the private National Irrigation Association, described anticipated benefits to "farmers' boys growing to manhood, who want the same chance . . . that their fathers had in the earlier days when land was easy to get in the great Mississippi Valley; or ... tenant farmers, longing to own the land they cultivate."8 Congressman Wesley Jones of Washington stressed the importance of what had come to be called the "agricultural ladder." He pictured reclamation as a way to preserve the opportunity for people to advance.

The great result froin this bill will be the happy homes that will be built in our own country and more loyal citizens to our flag and the principles it represents. To take the fruits of one's toil and give to another, to work froin day to day and eke out a mere miserable existence for oneself and family, to live without hope of bettering one's condition, is not conducive to noble manhood or loyal citizenship.?

This view of the reclamation bill and a proper role for farm labor was not unanimous. Gilbert M. Tucker, editor of The Country Gentleman magazine, spoke for eastern farmers who depended on hired laborers to work their farms and who feared "absorption by the free lands of the men and women who ought to supply, and in the normal condition of things would supply, an abundance of labor, at moderate wages, for established farmers."10

The issue was clear: Was the tiller to have a chance at independence on a farm of his own? Congress answered affirmatively by passing the reclamation bill to irrigate arid western lands. The bill's sponsors gave unstinted assurances that the acreage limitation and residency

6. 35 CONG. REc. 6734 (1902). The Mexican revolution had not yet broken out.

7. Id. at 6739.

8. S. Doc. No. 446, 57th Cong., 1st Sess. 29 (1902).

9. 35 CoNG. REC. 6755 (1902).

10. Id, at 6724 . 
requirement would effectively provide an opportunity for independent, individual farm ownership. Congressinan Eben W. Martin of South Dakota said: "The bill is drawn exclusively for the protection of the settler and actual homebuilder and every possible safeguard is made against speculative ownership and the concentration of the lands or water privileges into large holdings." 11

Congressman Frank Mondell of Wyoming assured Congress:

[The acreage limitation and residency provisions were] drawn with a view of breaking up any large land holdings which might exist in the vicinity of the Government works and to insure occupancy by the owner of the land reclaimed. . . .

No law ever presented to any legislative body has been so carefully drawn with a view of preventing the possibility of speculative ownership in lands. . . . ${ }^{12}$

Thus, historic national land policy was formulated to be applied to the irrigation of arid and semiarid western lands, both public and private.

\section{II}

Comrades: A little more than four months ago the Red Banner of the Proletariat floated on the battle fields of Mexico, sustained by emancipated workers, whose aspirations are epitomized in the sublime cry-"Land and Liberty."

\section{Liberal Party Manifesto (1911) ${ }^{13}$}

The course of agrarian affairs in Mexico stands in contrast to that in the United States. In 1910, rebellion followed the ousting of Dictator-President Porfirio Diaz. The following year, an illiterate sharecropper named Emiliano Zapata catalyzed open and widespread agrarian revolt. He issued his Plan de Ayala as a warning to Diaz's replacement Francisco Madero, a warning of the urgent necessity to press for agrarian reform.

The Plan declared:

Let Señor Madero-and with him all the world-know that we shall not lay down our arms until the ejidos of our villages are restored to us, until we are given back the lands which the hacendados stole from us during the dictatorship of Porfirio Diaz, when justice was subjected to his caprice. We shall not lay down our arms until we cease to be the unhappy tributaries of the despotic magnates and landholders of Morelos . . . . 14
11. Id. at 6758.
12. Id. at 6678 .
13. Translated in Simpson, The Ejwo: Mexico's Way OUt 49 n.14 (1937).
14. Id. at 51. Zapata was assassinated in 1919. 
For a decade Mexico was in turmoil as one leader replaced another. Whether agrarian reform would emerge as the central issue from military and political struggles for power was uncertain until Venustiano Carranza issued the Decree of 1915. Supporting the agrarian aspirations of the Mexican masses, the Decree took its place along with Zapata's Plan as a forerunner to article 27 of the Mexican Constitution. ${ }^{15}$ But despite proclamations and even a constitutional provision, realization of substantial land distribution came slowly, and spasmodically.

Not until the late 1930's, when President Lazaro Cardenas "distributed more land to the peasants than liad been distributed in all the years simce the beginning of the Revolution,"16 was major progress made in the land reform program. This distribution occurred after the high tide of emigration to the United States in the 1920's and during a period of repatriation under the impact of depression in the United States. ${ }^{17}$ At least temporarily, Mexico's political safety valve of emigration liad ceased to function.

III

Goodbye, my beloved country,

Now I am going away;

I go to the United States, where I intend to work.

Corrido, An Emigrant's Farewell (late 1920's). ${ }^{18}$

$* * *$

What they say about us

is nearly all the truth,

but we left the country

from sheer necessity.

Corrido, Defense of the Emigrants (late 1920's). ${ }^{10}$

In 1850 , just after the treaty transferring title to the Southwest, there were fewer than 14,000 people of Mexican birth in the United

15. Id. at 54. The decree recognized that villagers had been unable to protect their property and were left with no "recourse but to hire themselves out at ridiculous wages to the powerful landlords." Quoted in id. at 57.

16. L. SMMpson, Many Mexicos 288 (1952).

17. During the years $1930-33$, Mexico officially reported 306,628 repatriates. Taylor, Mexican Labor in the United States: Migration Statistics, 12 UNIV. CAL. PUBL. Econ. (1934). See also A. Hoffman, Unwanted Mexican Americans: Repatriation Pressures DuRING the Great Depression (1973).

18. Taylor, Songs of the Mexican Migration, in PUro Mexicano 222 (J. Dobie ed. 1935).

19. Id. at 238 . 
States. ${ }^{20}$ Over 12,000 of these resided in the southwestern states and territories where the Spanish pattern of large land grants prevailed. During the second half of the nineteenth century, migration from Mexico was meager and mainly confined to within 100 miles of the border, with migrants crossing and recrossing the border frequently. Not until 1908 did the United States Immigration Service even report the annual number of Mexican immirgants.

By the early 1900's construction of railways from the interior of Mexico to the international border enabled nore people to migrate. The flow was largely seasonal, migrants moving both ways, serving the labor needs of railway track construction and working the adjacent crops in the United States. This transborder movement began prior to the end of the Diaz regime and the outbreak of revolution in Mexico; still, the influence of agrarian dissatisfaction could already be discerned. A distinguished American observer commented in 1908:

What is sometimes called the "peon country" (the group of States

... [newly opened to emigration by the Mexican railways]) appears to be precisely where these little villages of feudal tenants are most common, and one of the most interesting secondary effects of the tide of emigration starting northward from this section to the United States is its probable influence in breaking up the patriarchal organization of agriculture and landholding in Mexico. ${ }^{21}$

The real surge of Mexican migration to the United States followed the displacement of Diaz in 1910. From 1905 to 1910, the United States Immigration Service had reported an estimated 21,732 immigrants from Mexico. Between 1915 and 1920 the number rose to 91,075. The Mexican Revolution, United States entry into World War I, and the enactment of quota laws in the 1920's limiting immigration from Europe stimulated immigration from Mexico. Between 1925 and 1930 the number of recorded Mexican immigrants reached 238,527, 10 times the number that had come 20 years earlier. ${ }^{22}$ The tightening of border controls, ${ }^{23}$ and the Great Depression brought heavy return novement to Mexico. Between 1930 and 1935, emigration from the United States expanded and immigration fell to a low of 19,200 . The level of immigration was not to imcrease again significantly until the 1950 's. ${ }^{24}$

20. Bureau of Census, Statistics, xxxvii (1850) (the figure given is 13,317).

21. Clark, Mexican Labor in the United States, 78 U.S. BUREAU LABOR BULL. 468 (1908).

22. L. Grebler, J. Moore \& R. Guzman, The Mexican-American People 64 (1970) [hereinafter cited as GREBLER] (the first figure for 1905-10 is an estimate).

23. Taylor, More Bars Against Mexicans?, 64 THE SURVEY 26 (1930).

24. GREBLER, supra note 22, at 64. 


\section{IV}

American laborers will not generally submit to the standard of living acceptable to the [immigrant] migratory farm labor of the West.

$$
\text { United States Immigration Commission (1911)..25 }
$$

If the farm labor of which we are now desperately in need could be secured from the congested centers within the United States we would not be here asking for help.

$$
\begin{aligned}
& \text { Harry A. Austin, Secretary, United States Sugar Manufacturers } \\
& \text { Association (1926).26 } \\
& \qquad * * *
\end{aligned}
$$

Somebody, somewhere, has to do hard physical labor because it is here to be done. . . . Under our present system of education, we must either bring somebody in here to do our hard work or we must go elsewhere for our foodstuffs and clothing.

$$
\begin{gathered}
\text { Ralph H. Taylor, Executive Secretary, Agricultural Legislative } \\
\text { Committee, California (1928). }{ }^{27}
\end{gathered}
$$

The high tide of immigration that brought 678,291 reported immigrants from Mexico between 1911 and $1930,{ }^{28}$ coincided with notable agricultural development in the five southwestern states of Arizona, California, Colorado, New Mexico, and Texas. The development was stimulated by federal reclamation of water resources, both underground and stored flood waters, and it spread rapidly to arid and semiarid lands. Production of fruits and vegetables which were to be sold largely in eastern markets, and of sugar beets, which enjoyed protective tariffs, expanded. Cotton growing, historically confined to the Cotton Kingdom of the South, rapidly moved west to Arizona and California.

The labor requirements for each of these crops were high in peak seasons but low in slack. The lack of continuous employment in the same crop and the same area made seasonal migration from region to region common.

This pattern, already familiar to the West, was directly attributable to the high concentration of landownership. James Bryce described this land and labor pattern prevalent in California as early as 1889:

25. IMMigRation COMM'N, IMMIGRANTS IN IndUSTRIES, S. Doc. No. 633, 61st Cong., 2d Sess. 151 (1911).

26. Hearings on Seasonal Agricultural Laborers from Mexico Before the House Comm. on Immigration and Naturalization, 69th Cong., 1st Sess. $251-52$ (1926).

27. Hearings on Immigration from Countries of the Westerm Hemisphere Before the House Comm. on Immigration and Naturalization, 70th Cong., 1st Sess. 307 (1928).

28. 1973 Immigration and Naturalization Service ANN. ReP. 54. 
When California was ceded to the United States, Iand speculators bought up large tracts under Spanish titles, and others, foreseeing the coming prosperity, subsequently acquired great domains by purchase, either from the railways which had received land grants, or directly from the government. Some of these speculators, by holding their lands for a rise, made it difficult for immigrants to acquire small freeholds, and in some cases checked the growth of farms. Others let their land on short leases to farmers, who thus came into a comparatively precarious and often necessitous condition; others established enormous farms, in which the soil is cultivated by hired labourers, many of whom are discharged after the harvest-a phenomenon rare in the United States, which is elsewhere a country of moderately sized farms, owned by persons who do most of the labour by their own and their children's hands. Thus the land system of Califormia presents features both peculiar and dangerous, a contrast between great properties, often appearing to conflict with the general weal, and the sometimes hard pressed small farmer, together with a mass of unsettled labour, thrown without work into the towns at. certain times of the year. ${ }^{20}$

During the 1890's, westerners gathered nearly every year at national irrigation congresses to seek ways to promote irrigation. They asserted that with the coming of water this landownership and labor pattern would be broken. As stated above, the devices Congress chose to enable more people to own land were the requirement that individuals receive water for no more than 160 acres and that they be residents on the land or in the neighborhood..$^{30}$

Writing these requirements into the 1902 statute, however, did not assure the occupation of western irrigated lands by farmers tilling their own soil. Several factors explain this gap between policy goals and their realization during this period of intensifying Mexican immigration. First, early projects in the Southwest, of which Imperial Valley was the largest, were privately constructed prior to passage of the 1902 Act. Therefore, federal reclamation law did not apply to them. Second, the construction of federal reclamation projects proceeded slowly. During the first 27 years of federal reclamation, while Mexican immigration was rising to the peak of the 1920 's, only $\$ 240$ million was spent on irrigation projects. During the next 27 years, after immigra-

29. 2 J. BRyce, The AMERICAN COMMONWEALth 427 (7th ed. 1923).

30. Taylor, Water, Land and the People in the Great Valley, 5 AM. WEST 24 (1968). See also epigraph accmmpanying note 1 supra. For land and labor background, see M. Cooper, Land, Water and Settlement in Kern County, California: 1850-90, Nov. 6, 1953 (unpublished master's thesis in the Graduate Social Science Library, Univ. of Cal., Berkeley); Hearings on Violations of Free Speech and Rights of Labor Before a Subcomm. of the Senate Comm. on Education and Labor, 74th Cong., 3d Sess. 19,777 (1940) [heremafter cited as Hearings on Free Speech]. 
tion had slackened, $\$ 3.2$ billion was spent. ${ }^{31}$ The great California Central Valley Project, for example, was not begun until the mid1930's, and still is incomplete. Third, the Arizona Salt River Project was authorized in 1903 under reclamation law, but the law's acreage limitation and residency provision have never been enforced there. ${ }^{32}$ Fourth, not until 1928 was Imperial Valley brought under reclamation law in the Boulder Canyon Project. Whether the law is to be enforced there is an issue currently before the courts. ${ }^{3 s}$

With construction of reclamation projects retarded and the antimonopoly and residency provisions of the law unenforced, immigrant Mexicans entering western agriculture filled the labor niche planned for them by large landed employers. As Bryce had noted in the 1880 's, landless laborers were employed seasonally in ever larger numbers and demied access to landownership. According to the 1970 census, only 4.3 percent of those born in Mexico and only 6.7 percent of the second generation, those born in the Umited States of Mexican parents, had become farmers or managers in the five southwestern states. ${ }^{34}$ The result of this agricultural labor pattern is the polarization of rural society in the western United States. While in the country as a whole, the average percentage of "farm personnel" belonging to the "lower class" in 1959 was 31.1 percent, in California the percentage was 55.7, and in Arizona 71.4. In Imperial Valley, California, where reclamation law is unobserved, the "lower class"

31. The Library of Cong. Legis. Ref. Serv., 86th Cong., 1st Sess., Report to THE HOUSE COMM. ON INTERIOR AND INSULAR AFFaIRS: RECLAMATION-ACCOMPLISHMENTS AND CONTRIBUtToNs 50 (Comm. Print No. 1, 1959).

32. When Congress was considering expansion of reclamation in that area in 1949, Congressman Donald Jackson of California explained:

Not one acre . . . would be available to veterans or other worthy Americans who wished to find farm homes. The great landowners, individuals, and corporations, own it and it is reasonable to assume in the light of past history, that they would take the profits from it.

It is true that under reclamation law, each individual ownership is entitled to 160 acres of irrigated land. . . .

True, the Bureau of Reclamation says that the 160-acre law will be enforced if the Arizona project is built. But we know that this law has never been enforced there. There is no reason to believe it will be enforced in the future. Rather, there is every reason to believe that it will not be enforced.

95 CONG. REC. 10,128 (1949). See also Hearings on S. 1425 Before the Subcomm. on Irrigation and Reclamation of the Senate Comm. on Interior and Insular Affairs, 85th Cong., 2d Sess. 231 (1958) [hereinafter cited as Hearings on S. 1425].

33. Compare Yellen v. Hickel, 352 F. Supp. 1300 (S.D. Cal. 1972) with United States v. Imperial Irrigation Dist., 322 F. Supp. 11 (S.D. Cal. 1971), appeals docketed and joined, Civil No. 73-1333 (9th Cir., Nov. 29, 1972) and Civil No. 73-1388 (9th Cir., Dec. 14, 1972). See also Taylor, Water, Land and Environment, Imperial Valley: Law Caught in the Winds of Politics, 13 Nat. REs. J. 1 (1973). 61,78 .

34. 1970 Bureau of Census, Subject Reports, Persons of Spanish Surnames 
mostly of Mexican birth or parentage, reached 87.3 percent. ${ }^{35}$

$\mathrm{V}$

This excess [urban] labor force grew larger over the years . . . as the growth of agribusiness forced more small farmers and farm workers off the land.

$$
\begin{gathered}
\text { Ira Eisenberg (1974). }{ }^{36} \\
* * *
\end{gathered}
$$

[M]ore than a year ago, 30 Chicano farm worker families formed a strawberry co-op, borrowed $\$ 175,000$ from Wells Fargo Bank and $\$ 100,000$ from the federal government.

Today, the bank loan is paid off, the co-op owns its own machinery and the workers are looking this year for an income between $\$ 9,000$ and $\$ 11,000$ a family. . . .

$$
\text { Joel Tlumak (1972).37 }
$$

Over the years Mexican immigrants to the United States have generally gathered together in barrios, neighborhoods where inherited culture and language survive through daily use. Rarely did immigrants apply for United States citizenship. Ultimate return to Mexico was thought of as normal, however improbable in actuality. Thus, in contrast to the previous experience of most migrations to the United States from Europe, Mexican assimilation was retarded for almost two generations. $^{38}$ Until they realized that their future lay in the United States, Mexican Americans had little reason to concern themselves with the land acquisition opportunity afforded them under reclamation law. ${ }^{39}$

Mexican Americans have accepted the role of farm wage worker though they have not been content with this role. Their record is one of protest in the form of strikes, boycotts, and a succession of attempts

35. Smith, A Study of Social Stratification in the Agricultural Sections of the U.S., 34 RURAL Sociol. 496, 506-08 (1969).

36. Eisenberg, The People and the Police, San Francisco Sunday Examiner \& Chronicle, May 26, 1974 (California Living), at 8.

37. San Francisco Sunday Examiner and Chronicle, Aug. 27, 1972, at 1, col. 6.

In the Salinas-Watsonville area, government funds (your tax dollars) are being used to help the disadvantaged get into farming. This is either good or bad depending upon one's political, social and economic point of view. It might be a good investment if a few hundred thousand of your dollars would get some families off welfare and into a productive, tax-paying position.

CAL. FARMer, June 17, 1972, at 7.

38. It is perhaps characteristic that a Mexican-American . . . whose parents lad iminigrated . . . remembers contimual family discussion of an early return to the homeland, until he himself, at the age of eighteen, recognized that "he was liere to stay."

GREBLER, supra note 22, at 63-64.

39. To this day no Mexican American has clallenged in court the failure of administrators to enforce acreage limitation and residency provision along the Salt River in Arizona. C $f$. the stateinent of Congressman Jackson quoted supra note 31. 
to organize and bargain collectively with their employers..$^{10}$ Nonenforcement of reclamation law cannot be accurately explained by the indifference or inaction of the landless-Mexican Americans among them. The central problem arose from the fact that potentially irrigable lands had largely passed into private hands long before public reclamation became a reality. This created special interests resistent to the controls over monopoly and speculation incorporated in the 1902 reclamation law. As early as 1877, this fact was noted in California's Central Valley:

$[\mathrm{N}] \mathrm{o}$ one would believe that shrewd, calculating businessmen would invest their money on the strength of this land rising in value while unimproved, for even the farmer himself has to abandon it who endeavors to add to its value without water. At the same time, purchasers are not lacking who would add it to their already extensive dry domain and the people... will find themselves confronted by an array of force and talent to secure to capital the ownership of the water as well as of the land, and the people will at last liave it to pay for. ${ }^{41}$

An early study by the Bureau of Reclamation disclosed a 759 percent increase in land value attributable to irrigation. ${ }^{42}$ To prevent these windfall profits by large landowners, Congress prescribed in 1926 that the sale price of excess lands be limited to their value "without reference to the proposed construction of the irrigation works." 43 Enactment of the 1926 statute did not assure its enforcenient, nor end disputes over the allocation of the additional value, however.

The longer the owners of excess lands were allowed by administrative ruling to postpone sale after the coming of water, the greater the chance for gain. As Harry W. Horton, Chief Counsel of Imperial Irrigation District, testified to Congress in reference to a ruling allowing 10 years time to sell the excess:

Let us lay the cards on the table . . . . I will give you my own opinion of Jack O'Neill's willingness to sign the 160-acre limitation. He thinks if lie gets water for 10 years on there without having to sell it, he can make enough money out of it so he can afford to sell it at any old price. ${ }^{44}$

40. See E. Galarza, Merchants of Labor (1964); E. Galarza, Spiders in the HOUSE AND WORKERS IN THE FIELD (1970). See also Hearings on Free Speech, supra note 30 , at $17,207-20$.

41. The Visalia Delta [Cal.], May 5, 1877, at 2, col. 3.

42. Hearings on Exemption of Certain Projects from Land-Limitation Provisions of Federal Reclamation Laws Before a Subcomm. of the Senate Public Lands Comm., 80th Cong., 1st Sess. 204 (1947).

43. 43 U.S.C. $\$ 423$ (e) (1926).

44. Hearings on $S$. 1425, supra note 32 , at $87-88$. 
Nearly a quarter of a century after enactment of the original reclamation law a citizens' committee of special advisers appoimted by the Secretary of the Interior had recommended that "weaknesses in the original law [should] be corrected, since they are largely responsible for the difficulties that have arisen and are still apparent in the execution of the reclamation act." 45 Their report had stated:

Although the Reclamation Service attempted to compel the subdivision of these privately owned lands into the units fixed by law, yet the legal enforcement was found difficult; and what was still worse, in many cases the owners of the land capitalized the Government expenditures and the liberality of its terms of repayment by selling the lands to the settlers at much higher prices than could otherwise have been obtained. The benefits of the reclamation act, therefore, went in such cases almost entirely to these speculative owners . . . . 46

In 1926, within two years of the committee report, Congress had sought to rectify this weakness by prescribing that the windfall profits from reclamation projects initiated after 1926 should not go to owners of excess land. It declared:

[A]ll irrigable land held in private ownership by any one owner in excess of one hundred and sixty irrigable acres shall be appraised . . . and the sale prices thereof fixed by the Secretary on the basis of its actual bona fide value at the date of appraisal without reference to the proposed construction of the irrigation works . . . .47

Here agam a reclamation statute was to prove wanting. No civil or criminal penalties were prescribed for violation of the law by a recipient of project water. Administrative interpretations of the ineaning of "without reference to the proposed construction of the irrigation works" were arrived at in a relaxed atmosphere. Neither observance nor enforceinent was forthcoming. In 1965, for example, when the DiGiorgio Corporation was divesting itself of excess lands in DelanoEarlimart and Arvin-Edison water districts in California's Central Valley, the corporation distributed a fact sheet among prospective purchasers. With reference to sale prices it said: "The Bureau has indicated that it will not withhold approval for any transaction within reason." 48

The issue persists: Should the excess landowner, the purchaser of excess land, or the public treasury receive the profit created by reclamation? In Ivanhoe v. McCracken, ${ }^{49}$ the United States Supreme Court

45. S. Doc. No. 92, 68th Cong., 1st Sess. 38-39 (1924).

46. Id.

47. 43 U.S.C. $\S 423(\mathrm{e})(1926)$.

48. Letter from Di Giorgio Corp. to all interested parties, Aug. 27, 1965, on file in California Law Review offices.

49. Ivanhoe v. McCracken, 357 U.S. 275 (1958). 
indicated that the benefit was not to inure solely to the large landowner. According to the Court:

The project was designed to benefit people, not land. It is a reasonable classification to limit the amount of project water available to each individual in order that benefits may be distributed in accordance with the greatest good to the greatest number of individuals. The limitation insures that this enormous expenditure will not go in disproportionate share to a few individuals with large land holdings. Moreover, it prevents the use of the federal reclamation service for speculative purposes. ${ }^{50}$

In 1970, the Public Land Law Review Commission recommended the acreage limitation and residency requirement be abandoned in an age of expensive technology which requires large land loldings to make agricultural industry economically feasible.51 Three years later the National Water Commission professed that "it would not do to abohish the limitation if the effect would be to confer large windfall gains on reclamation farmers;" hand, it recommended waiver of acreage limitation at the option of irrigation districts or landowners if money payments were made, though the paynents admittedly "would not fully recapture the subsidy granted to irrigation water."53

Subsidy and wimdfall profits are not the same. While the Natural Water Commission recommended abolition of subsidy on future projects, it was silent on windfall profits. Apparently it relies on its contractor who, in substance, lolds the view that reclamation law is unconcerned with windfall profits. For despite the 1926 language requiring that the sale price of excess land be set "without reference to the proposed construction of the irrigation works," the contractor contends:

A landowner has a right to be compensated . . . for what the market determines [his excess land] . . . to be worth. . . . The advent of project water is typically discounted in land value long years before the arrival of the water on the project lands. This being the case, the [purchaser of] . . . pre-project lands would pay close to a price for land that reflected its post-project value. . . .54

Apparently the National Water Commission accepts this view of the innocuousness of congressional legislation.

50. Id. at 297.

51. Public Land Law Review Commission, ONe Third of the Nation's Land 182-84 (1970). (1973).

52. National Water Commission, Water Policies for the Future 148

53. Id. at 149.

54. H. Hogan, The ACreage Limttation in the Federal Reclamation Program 289 (Nat'l Tech. Inf. Serv. Publ. 1972). The National Water Commission stated that the "backgrouud and operation of the acreage limitation . . . [were] taken largely" from the report of Mr. Hogan. NATtonal WATER Commission, supra note 52, at 142. 
An alternative to the views of the two Commissions was placed before both Houses of Congress but did not receive a hearing. This proposal, called the Reclamation Lands Authority Act, built upon the 1926 language "without reference to the proposed construction of the irrigation works," and would have made it administratively effective by authorizing the government itself to purchase the excess lands. This would have diverted the windfall profits created by public reclamation into the public treasury, ${ }^{55}$ and assured a lower investment cost to the landless person acquiring a farm under reclamation law.

\section{VI}

This timely movement, looking to the reclamation of Arid America, thus giving "land to the landless," ranks in real importance with the foremost public measuers of the times.

$$
\text { Harrison Gray Otis (1902) })^{56}
$$

Applicants [for permission to intervene in suit to compel observance of acreage limitation law] have shown no present ability to purchase and no prior offers within the past twenty years to purchase farm land in the Imperial Valley at market value . . . .

Judge Howard B. Turrentine (1971).57

Despite comprising one-third of the population of Imperial Valley and most of its agricultural labor force, Mexican Americans did not challenge nonobservance of reclamation law in the Valley. The Government acted first. Based on a 1964 opinion by the Solicitor of the Interior, the Government, after some 30 years of nonenforcement, brought suit in 1967 to enforce acreage limitation in the Valley. ${ }^{58}$

The next move was made by a Valley plysician from Brooklyn who undertook active support of the Government's case. "Dr. Yellen rounded up 123 non-landowners-many of them farm-workers who could not get jobs because the big growers use illegal Mexican laborand hired a lawyer to file an amicus brief on their behalf ....".59 A local newspaper reported:

Most of the petitioners are farm workers who have been or are now employed as agricultural laborers .... None presently own farm land anywhere in the United States.

55. S. 2863, H.R. 5236, 92 d Cong., 1st Sess. (1971); 117 Cong. Rec. 11,201-02 (1971) (remarks of Rep. Kastenmeier).

56. Proceedings of the Ninth National Irrigation Congress, Chicago, 240.

57. Ben Yellen, Application to Intervene, Umited States v. Imperial Irrigation Dist., Civil No. 67-7-T (S.D. Cal., March 29, 1971).

58. United States v. Imperial Irrigation Dist., 322 F. Supp. 11 (S.D. Cal. 1971), appeal docketed, Civil No. 73-1388 (9th Cir., Dec. 14, 1972).

59. Kinsley, Ben Yellen's Fine Madness, 2 Wash. Monthly, January 1971, at 44. 
Most of the privately-owned irrigable land within Imerpial Irrigation District is owned by persons who do not reside on or near such lands. All of the petitioners desire to own land of their own upon which to engage in farming; and to be able to purchase irrigable lands within IID which will be sold if the government obtains a favorable decision in the case. ${ }^{60}$

In 1971 federal district court Judge Howard B. Turrentine ruled against the Government and held that the acreage limitation does not apply to privately-owned land in Imperial Valley. ${ }^{61}$ Anticipating that the Government might not appeal, Dr. Yellen sought to intervene and thereby allow the landless to appeal. Judge Turrentine denied the niotion, ${ }^{62}$ the Government did not appeal. ${ }^{63}$

Meanwhile, Yellen and his landless litigants raised the issue of residency in a separate suit. Residency is the coinpanion requirement to acreage limitation and compels the water receiver to be "an actual bona fide resident on such land, or occupant thereof residing in the neighborhood of said land ...."

Despite Judge Turrentine's holding the acreage limitation inapplicable to Imperial Valley, Judge William D. Murray held the residency provision applicable to the Valley and to reclamation projects generally. Judge Murray wrote:

Failure to enforce residency subverts the excess land himitation. . . . Through the use of corporations, trusts and cotenancies flagrant violations of the purpose of this limitation are possible. Each of these farms may be used to by-pass the acreage limitation. The policy behind reclamation law to aid and encourage owner operated farms requires enforcement of the residency requirement to prevent these violations.

The fact that residency has not been required by the Department of Interior for over 55 years cannot influence the outcome of this decision. Failing to apply the residency requirement is contrary to any reasonable interpretation of the reclamation law as a whole, and it is destructive of the clear purpose and intent of national reclamation policy. It is well settled that adininistrative practice cannot thwart the plain purpose of a valid law. Rather than indicate the validity of the administrative ruling, the lapse of time serves to dramatize the

60. Brawley Advertiser [Cal.], August 9, 1967, at 1, col. 6.

61. United States v. Imperial Irrigation Dist., 322 F. Supp. 11 (S.D. Cal. 1971).

62. See note 57 supra.

63. See Hearings on Farmworkers in Rural America Before the Subcomm. on Migratory Labor of the Senate Comm. on Labor and Public Welfare, 92d Cong., 1st \& 2d Sess., pt. 3A, at 833 (1971-72) [hereinafter cited as Hearings on Farmworkers].

64. 43 U.S.C. $\$ 431$ (1902). See also epigraph accompanying note 1 supra. 
unavailability of relief in the past and points toward the need for increased access to the court in the future. ${ }^{65}$

The companion issues of acreage limitation and residency have now advanced to the Ninth Circuit Court of Appeals. ${ }^{68}$ That court has joimed them for a common hearing, and im addition has granted litigant standing to Yellen and his landless. Whichever way the Circuit Court decides, appeal to the Supreme Court may be expected.

Against these significant steps toward judicial recognition of the stake of landless persons in gaining access to land in the Imperial Valley, stands the absence of challenge by the landless of other valleys who allow widespread nonenforcement of reclamation law to continue. ${ }^{67}$

VII

[We small farmers and farm workers] have so many problems in common and so many common interests that we should unite for our joint survival.

\section{Dolores Huerta, Vice President of United Farm Workers Organizing Committee (1972). ${ }^{68}$ $\approx * \approx$}

The working farmer who does his own work, and whose product when placed on the market comes into competition with products of other farmers, prefers high wage scales so that the cost of labor entering into the goods of his competitors will force up the selling price of goods and hence give to him the high returns.

\section{R.L. Adams, Professor of Farm Management (1939). ${ }^{69}$}

Among Mexican Americans there has been no movement to acquire land for farming. The attention of those engaged in agriculture has been absorbed in the daily problems of employment, wages, housing and working conditions. Recently, however, a sinall number of

65. Yellen v. Hickel, 335 F. Supp. 200, 208 (S.D. Cal. 1971) (citations omitted). See also Yellen v. Hickel, 352 F. Supp. 1300 (S.D. Cal. 1972).

66. See note 33 supra.

67. Exceptions are rare. On February 7, 1970, Joe Ramon and Bruno Cavazos, farm workers owning five and 17 acres respectively, brought suit in Northern California Federal District Court to compel enforcement of the 160-acre law in the Delano-Earlimart Irrigation District, but the case has not been pressed. Ramon v. Delano-Earlimart Irrigation Dist, Civil No. C-70-299 (N.D. Cal., filed Feb. 7, 1970).

In the same District Court, four family farmers-not Mexican Americans-filed a similar suit to enforce federal reclamation law with respect to the California State Water Project. Bowker v. Morton, Civil No. C-70-1274 (N.D. Cal., Aug. 2, 1973). Following district court decisions adverse to plaintiffs, the Ninth Circuit granted leave to appeal. Bowker v. Morton, Civil No. 75-8126 (9th Cir., May 2, 1975).

68. Hearings on Farmworkers, supra note 63, pt. 3C, at 1784.

69: Hearings on Free Speech, supra note 30, at 17,218. 
labor-intensive cooperative farming projects have been undertaken, and initial results have raised excited hopes for expansion.

[An 80-acre strawberry cooperative in the Salinas-Watsonville area] produces revenues of $\$ 650,000$ to $\$ 700,000$. Approximately half of that is expense . . . The remaining $\$ 350,000$ then is rechanneled back as farm incoine. The farm incoine then is the income earned as a result of the labor they have invested. So therefore, each family approximately will be making $\$ 8,000$ to $\$ 10,000$ next year with about a $\$ 2,000$ net equity in the cooperative. ${ }^{70}$

A second project has attracted the attention of farm workers in the Fresno area. As described in Las Noticias:

They decided to grow 5 acres of cherry toinatoes. . . . Just as planned, everyone is working long hours, 7 days a week to make this the best crop in the valley. The result has been a complete success. So far the harvest of the 5 acres has been producing well over $\$ 1,000$ per day in sales, and in the daily inarketing reports for tomatoes, the price that Rancho El Bracero receives is always one of the top prices in the valley. The 40 acres is completely level now, and as soon as the harvest is over, the coop will plant a fall crop of grain on the full 40 acres. In 1974 they will be ready for full vegetable production.

All of the coop neinbers are very proud and happy to be working for themselves on their own farm. This is certainly the main reason for their tremendous success in farming. ${ }^{71}$

Enthusiastic accounts of a few projects, however, do not alter the fact that overwhelmingly Mexican Americans in agriculture remain landless workers for wages. Their daily conditions are affected directly by their ability to organize in unions. In a 1972 colloquy between Senator Adlai E. Stevenson III, and Dolores Huerta, of the Umited Farm Workers Union, the issues and alternatives emerged clearly.

Senator Stevenson. The Umited Farm Workers Organizing Committee has been very active in organizing farmworkers for the purpose of collective bargaining and the inprovement of working conditions, but do you think that a dreain of the farmworker is not to work for a wage but it is to own his own land, and to farm it with his own hands?

Ms. Huerta. It is a nice dreain, but where do you get the money to buy the land? . . .

Senator Stevenson. If the Federal programs are available, why shouldn't farmworkers take advantage of them, get the credit that they need both for the acquisition of land equity, and become farm owners?

70. Hearings on Farmworkers, supra note 63, pt. 1, at 158.

71. Las Noticias, Sept. 1973 (Organ of West Side Planning Group, Inc., $1476 \mathrm{~N}$. Van Ness, Fresno, California, 93728, a nonprofit community economic development corporation). 
Ms. Huerta. That would be beautiful, Senator, if it could become a reality.

Senator Stevenson. You seem to be more interested and preoccupied with simply negotiating and improving the working conditions of wage earners.

Ms. Huerta. Senator, if we are having trouble getting wages of $\$ 1.90$ and $\$ 2$ an hour for farmworkers . . . and you are talking now about making it possible for them to get money to buy land, this is a beautiful dream and I think we have to be practical. ${ }^{72}$

Are improvement of working conditions of farm workers, and enhancement of access to one's own land, mutually exclusive alternatives? In forming their practical answer to this question Mexican Americans will have to weigh their own interests, and decide what effort they will make to obtain effective enforcement of a reclamation policy that has been on the books for two full generations.

If a national policy is to be effective under the American system of government, each of the three branches of government must fulfill its relevant functions. If Mexican Americans conclude they have interests in reclamation law that are not now being properly served, they should approach the administration, the legislature, and the courts. They can protest the lax enforcement of the laws in the media, or in communications to congressional committees. Administrators may respond to pressures that may jeopardize their project authorizations or appropriations. ${ }^{73}$

Mexican Americans may conclude that reclamation law itself requires amendment to improve its enforceability, to redistribute excess land to the landless, to broaden its public service, to finance public education in the land grant tradition, or to preserve open space and familysize-farms on prime agricultural land. They then should evaluate pending legislation in the Congress, ${ }^{74}$ and give or withhold their active support.

The courts are available to redress and forestall violations by administrators who fail to observe and enforce the acreage limitation and residency requirement of reclamation law. Mexican Americans can bring suit for enforcement of the law in other reclamation areas as they have done in Imperial Valley. ${ }^{75}$ In ways sucli as these, Mexican

72. Hearings on Farmworkers, supra note 63, pt. 3C, at 1773-74.

73. W. Warne, The Bureau of Reclamation 218-22 (1973).

74. See, e.g., 117 CoNG. REC. 11,201 (1971) (remarks of Rep. Kastenmeier).

75. Taylor, Water, Land, and Environment, Imperial Valley: Law Caught in the Winds of Politics, 13 NAT. RES. J. 1 (1973). Among documented yet judicially unchallenged examples of apparent nonenforcement of acreage limitation law are the following, each involving substantial amounts of land: (1) Salt River Valley, Arizona. See, 95 
[Vol. 63:732

Americans can nrake their United States citizenship effective in serving their best interests and in giving meaning to their participation in the social, political, and economic life of this nation.

CoNG. Rec. 10,126 (1949); Hearings on S. 1425, supra note 32, at 231-38. (2) Southern California. See Statement of Chief Counsel Reginal L. Knox, Imperial Irrigation Dist., in Imperial Irrigation District News, Feb. 1965, at 1. (3) Sacramento River diverters, California. See Hearings on H.R. 3300 Before a Subcomm. of the House Comm. on Interior and Insular Affairs, 90th Cong., 1st Sess., at 686-87 (1967). 